\title{
Does the impact of metabolic syndrome on cardiovascular events vary by using different definitions?
}

\author{
Hossein Khosravi-Boroujeni ${ }^{1}$, Faruk Ahmed ${ }^{1}$, Masoumeh Sadeghi ${ }^{2}$, Hamidreza Roohafza ${ }^{2}$, Mohammad Talaei ${ }^{3}$, \\ Minoo Dianatkhah ${ }^{4}$, Ali Pourmogaddas ${ }^{4}$ and Nizal Sarrafzadegan ${ }^{4}$
}

\begin{abstract}
Background: Metabolic Syndrome (MetS) is a complex disorder which increases the risk of chronic diseases, including cardiovascular diseases and diabetes mellitus. As a result of modern lifestyles, the prevalence of MetS has been rising globally. This study aims to investigate whether overall prevalence of MetS varies when using different definitions of MetS and to identify the best and most predictive definition of the MetS for cardiovascular disease (CVD) events over 10 years in a cohort of an Iranian population.

Method: Adults aged $\geq 35$ years from urban and rural regions in central Iran were selected at baseline and followed up for more than 10 years. Data on socio-demographic characteristics, anthropometry, blood pressure and smoking status were collected at baseline. In addition, various biochemical indices were assessed. MetS was defined based on five available definitions, and cardiovascular events during 10 years follow up were confirmed by an expert group. The hazard ratios were calculated by the Cox proportional hazards model.

Results: The highest prevalence of MetS was observed by using AHA-NHBI definition (36.9\%), followed by JIS definition (31.2\%). On the other hand, EGIR (8.8\%) provided the lowest prevalence. The risk of developing CVD, irrespective of definitions, was approximately two fold higher in the presence of MetS. After controlling for possible confounders, AHA-NHBI definition was found to be the best predictor of CVD.

Conclusion: This study demonstrated a great variability in the prevalence of MetS among Iranian adults when using different definitions of MetS. CVD risk was significantly higher in MetS participants, as well as in participants with any risk factors of MetS; however, the AHA-NHBI definition was found to be the best predictor of CVD. Thus protective measures, including lifestyle modifications, plus control of individual risk factors is necessary to prevent cardiovascular events.
\end{abstract}

Keywords: Metabolic syndrome, Obesity, Diabetes, Hypertension, Cardiovascular diseases

\section{Background}

Metabolic Syndrome (MetS) is a complex disorder with a collection of related metabolic risk factors which increase the risk of developing chronic diseases, such as atherosclerotic cardiovascular disease (ASCVD) and diabetes mellitus [1]. MetS is also associated with other disorders such as fatty liver [2], cholesterol gallstones [3], polycystic

\footnotetext{
* Correspondence: nsarrafzadegan@gmail.com

${ }^{4}$ Isfahan Cardiovascular Research Center, Cardiovascular Research Institute, Isfahan University of Medical Sciences, Isfahan, Iran

Full list of author information is available at the end of the article
}

ovary syndrome [4], and sleep apnea [5]. In addition, it poses a significant risk of higher morbidity, mortality and financial burden [6]. The prevalence of MetS has been rising in both developed and developing countries, probably as a consequence of modern lifestyle and the overweight/obesity epidemic [7]. Therefore, MetS is considered a public health, as well as a clinical, problem. During the past decades, due to major lifestyle changes and aging population, the prevalence of MetS, cardiovascular diseases (CVD) and other chronic diseases has been increasing in Iran [8]. Based on a national study, MetS has been diagnosed in 34.7 to $37.4 \%$ 
of the Iranian population [9]. Moreover, high incidence rates for almost all CVD and mortality have been reported in the Iranian population [10].

The etiology of MetS has not been clearly defined, thus the definition of MetS is not based on etiology and pathology, but on the predictors of CVD as a primary outcome of MetS. It's diagnostic criteria have been developed on the basis of best clustering of interrelated risk factors of CVD which occur simultaneously and can predict CVD events [11]. In the past, several expert groups have attempted to develop practical diagnostic criteria to characterize individuals who are at high risk of CVD. They included underlying and metabolic risk factors, characterized by insulin resistance or impaired blood glucose, central obesity, dyslipidemia (increase in triglycerides and decrease in high density lipoprotein cholesterol (HDL) levels) and hypertension. However, the suggested criteria varies to some extent and some individuals might diagnose with one or two definitions but not with others [12-14].

Because there is no exclusive definition for the diagnosis of MetS, its prevalence, incidence and its association with an increased risk of cardiovascular diseases depends on the criteria used [15]. Thus, this study aims to investigate whether the prevalence of MetS varies when using different definitions of MetS in an Iranian population. In addition, it aims to determine the definition that is the best predictor for CVD events over 10 years in a cohort of an Iranian population.

\section{Methods}

\section{Study design}

The Isfahan Cohort Study (ICS) is an ongoing, population based, longitudinal study of adults aged $\geq 35$ years, from urban and rural regions in central Iran. It is designed to display the incidence of CVD and its risk factors, and to determine the Iranian risk assessment values. Participants were selected between January and September 2001 by multistage random sampling and were enrolled to represent the age, gender and urban/ rural distribution of their societies. The study details are presented elsewhere [16]. The study was approved by the Ethics Committee of the Isfahan Cardiovascular Research institute (ICRI) a World Health Organization (WHO) collaborating center and the Griffith University Ethics Committee.

\section{Measurements}

After obtaining the informed written consent of participants, physical examinations, fasting blood samples, and anthropometric measurements were carried out. Serum triglycerides, fasting blood glucose (FBG), and total cholesterol (TC), were determined using the enzymatic method [17]. Serum HDL-C was measured after precipitation of low density lipoprotein (LDL) and very low-density lipoprotein (VLDL) [18]. The LDL level was calculated by Friedewald formula [19]. Weight and height were measured by a calibrated scale and stadiometer with participants wearing light clothes and no shoes. Waist circumference (WC) was measured with non-elastic measuring tape at or below the costal margin (minimal waist) without compressing the tissue. Blood pressure was taken twice at 5 min interval in a sitting position with a mercury sphygmomanometer with an appropriate cuff for adults. The mean value of the two measurements was calculated and applied.

\section{Metabolic syndrome definitions}

Among the available definitions for MetS, this study selected the most widely practiced definitions which were developed by various international expert groups and organizations. The MetS was defined according to five definitions (Table 1). Based on the WHO definition, insulin resistance is required for diagnosing MetS, along with two other risk factors among central obesity, high triglyceride, low HDL or hypertension [12]. The European Group for Study of Insulin Resistance (EGIR) defined MetS only for non-diabetic people [20]. The National Cholesterol Education Program, Third Adult Treatment Panel (NCEP ATP III) did not emphasise any risk factors, but the presence of any 3 of the 5 risk factors would qualify a person for MetS [14]. Based on the International Diabetes Foundation (IDF), abdominal obesity is a requirement in MetS definition, and having central obesity plus any other two risk factors are required for the diagnosis of MetS [13]. This definition insists on easy-to-use measures in clinical practice, and moreover, emphasises ethnic differences in recognising the cut-off point of abdominal obesity [21]. The American Heart Association (AHA) and the National Heart, Lung, and Blood Institute (NHLBI) accepted the ATP III definition, but reduced the threshold for impaired glucose tolerance (IFG) from 110 to $100 \mathrm{mg} / \mathrm{dl}$ [22]. A harmonized definition of MetS (a Joint Interim Statement (JIS)) formulated by several organizations including IDF, NHLBI, AHA, the World Heart Federation, the International Atherosclerosis Society and the International Association for the Study of Obesity attempted to develop a unified criteria for defining MetS. They agreed that a single cut-off point for WC is not suitable and should not be a required component. Furthermore, any 3 out of 5 components are adequate for MetS diagnosis [11].

\section{Follow up}

With the purpose of verifying CVD events, the followup of participants was conducted using telephone call interviews and home visits when required, every two years. The participants were asked about their hospital 
Table 1 Different definitions of metabolic syndrome

\begin{tabular}{|c|c|c|c|c|c|c|}
\hline & WHO & EGIR & NCEP ATP III & $\mathrm{AHA}$ & IDF & JIS \\
\hline Definitions & $\begin{array}{l}\text { insulin resistance together } \\
\text { with two or more of the } \\
\text { following: }\end{array}$ & $\begin{array}{l}\text { Insulin resistance or impaired } \\
\text { fasting glucose (IFG) plus two } \\
\text { of the following: }\end{array}$ & $\begin{array}{l}\text { Three or more of the } \\
\text { following five risk factors: }\end{array}$ & $\begin{array}{l}\text { Three or more of the } \\
\text { following five risk factors: }\end{array}$ & $\begin{array}{l}\text { Central obesity plus } 2 \\
\text { other features }\end{array}$ & $\begin{array}{l}\text { Three or more of the } \\
\text { following five risk factors: }\end{array}$ \\
\hline $\begin{array}{l}\text { Fasting plasma } \\
\text { glucose }\end{array}$ & - & $\begin{array}{l}\geq 6.1 \mathrm{mmol} / \mathrm{l}(110 \mathrm{mg} / \mathrm{dl}) \\
\text { but non-diabetic }\end{array}$ & $\geq 6.1 \mathrm{mmol} / \mathrm{l}(110 \mathrm{mg} / \mathrm{dl})$ & $\geq 5.6 \mathrm{mmol} / \mathrm{l}(100 \mathrm{mg} / \mathrm{dl})$ & $\begin{array}{l}\geq 5.6 \mathrm{mmol} / \mathrm{l}(100 \mathrm{mg} / \mathrm{dl}) \\
\text { or diagnosed type } 2 \\
\text { diabetes }\end{array}$ & $\begin{array}{l}\geq 5.6 \mathrm{mmol} / \mathrm{l} \\
(100 \mathrm{mg} / \mathrm{dl})\end{array}$ \\
\hline \multirow[t]{2}{*}{$\begin{array}{l}\text { Central } \\
\text { obesity }\end{array}$} & Men: waist-hip ratio $>0.90$ & $\begin{array}{l}\text { Men: waist circumference } \\
\geq 94 \mathrm{~cm}\end{array}$ & $\begin{array}{l}\text { Men: waist circumference } \\
>102 \mathrm{~cm}\end{array}$ & $\begin{array}{l}\text { Men: waist circumference } \\
>102 \mathrm{~cm}\end{array}$ & $\begin{array}{l}\text { Men: waist circumference } \\
\geq 94 \mathrm{~cm} \text {, }\end{array}$ & $\begin{array}{l}\text { Ethnic cut point for waist } \\
\text { circumference }^{a}\end{array}$ \\
\hline & $\begin{array}{l}\text { Women: waist-hip ratio > } 0.85 \\
\text { and/or } \mathrm{BMl}>30 \mathrm{~kg} / \mathrm{m} 2\end{array}$ & $\begin{array}{l}\text { Women: waist } \\
\text { circumference } \geq 80 \mathrm{~cm}\end{array}$ & $\begin{array}{l}\text { Women: waist } \\
\text { circumference }>88 \mathrm{~cm}\end{array}$ & $\begin{array}{l}\text { Women: waist } \\
\text { circumference }>88 \mathrm{~cm}\end{array}$ & $\begin{array}{l}\text { Women: waist circumference } \\
\geq 80 \mathrm{~cm}^{\mathrm{a}} \text { or } \mathrm{BMI}>30 \mathrm{~kg} / \mathrm{m}^{2}\end{array}$ & \\
\hline Blood pressure & $\geq 140 / 90 \mathrm{mmHg}$ & $\begin{array}{l}\geq 140 / 90 \mathrm{mmHg} \text { or } \\
\text { treatment }\end{array}$ & $\geq 130 / 85 \mathrm{mmHg}$ & $\geq 130 / 85 \mathrm{mmHg}$ & $\begin{array}{l}\geq 130 / 85 \mathrm{mmHg} \text { or } \\
\text { treatment }\end{array}$ & $\geq 130 / 85 \mathrm{mmHg}$ \\
\hline Triglycerides & $\geq 1.7 \mathrm{mmol} / \mathrm{l}(150 \mathrm{mg} / \mathrm{dl})$ & $>2.0 \mathrm{mmol} / \mathrm{l}(178 \mathrm{mg} / \mathrm{dl})$ & $\begin{array}{l}\geq 1.7 \mathrm{mmol} / \mathrm{l}(150 \mathrm{mg} / \mathrm{dl}) \text { or } \\
\text { treatment }\end{array}$ & $\begin{array}{l}\geq 1.7 \mathrm{mmol} / \mathrm{l}(150 \mathrm{mg} / \mathrm{dl}) \\
\text { or treatment }\end{array}$ & $\begin{array}{l}\geq 1.7 \mathrm{mmol} / \mathrm{l}(150 \mathrm{mg} / \mathrm{dl}) \\
\text { or treatment }\end{array}$ & $\begin{array}{l}\geq 1.7 \mathrm{mmol} / \mathrm{l}(150 \mathrm{mg} / \mathrm{dl}) \\
\text { or treatment }\end{array}$ \\
\hline \multirow[t]{2}{*}{$\begin{array}{l}\text { HDL- } \\
\text { cholesterol }\end{array}$} & Men: $<0.9 \mathrm{mmol} / \mathrm{l}(35 \mathrm{mg} / \mathrm{dl})$ & $\begin{array}{l}<1.0 \mathrm{mmol} / \mathrm{l}(39 \mathrm{mg} / \mathrm{dl}) \\
\text { or treatment }\end{array}$ & $\begin{array}{l}\text { Men: }<1.03 \mathrm{mmol} / \mathrm{l}(40 \mathrm{mg} / \\
\mathrm{dl})\end{array}$ & $\begin{array}{l}\text { Men: < } 1.03 \mathrm{mmol} / / \text { ( } 40 \mathrm{mg} / \\
\mathrm{dl})\end{array}$ & $\begin{array}{l}\text { Men: }<1.0 \mathrm{mmol} / \mathrm{l} \\
(39 \mathrm{mg} / \mathrm{dl})\end{array}$ & $\begin{array}{l}\text { Men: }<1.03 \mathrm{mmol} / \mathrm{l} \\
(40 \mathrm{mg} / \mathrm{dl})\end{array}$ \\
\hline & $\begin{array}{l}\text { Women: < } 1.0 \mathrm{mmol} / \mathrm{l} \\
(39 \mathrm{mg} / \mathrm{dl})\end{array}$ & & $\begin{array}{l}\text { Women: < } 1.29 \mathrm{mmol} / \mathrm{l} \\
(50 \mathrm{mg} / \mathrm{dl})\end{array}$ & $\begin{array}{l}\text { Women: }<1.29 \mathrm{mmol} / \mathrm{l} \\
(50 \mathrm{mg} / \mathrm{dl})\end{array}$ & $\begin{array}{l}\text { Women: }<1.3 \mathrm{mmol} / \mathrm{l} \\
(40 \mathrm{mg} / \mathrm{dl}) \text { or treatment }\end{array}$ & $\begin{array}{l}\text { Women: } \\
<1.29 \mathrm{mmol} / \mathrm{l}(50 \mathrm{mg} / \mathrm{dl})\end{array}$ \\
\hline
\end{tabular}

based on Iranian cut off point, Waist Circumference $\geq 95$ for both sexes 
admissions or any cardiac or neurological symptoms that led to visiting a physician. In 2007 and 2013, interviews, physical examinations and laboratory tests were repeated for all participants. The measurement methods were similar to the 2001 survey. Acute myocardial infarction (AMI), unstable angina (UA), and sudden cardiac death were considered as the indicators of ischemic heart disease. A panel of three cardiologists and one neurologist, unaware of the data related to risk factors, examined all the documents to confirm the CVD cases. For the purpose of this study, the data on CVD event were recorded up to the 2013 survey.

\section{Statistical methods}

The prevalence of MetS was calculated by using different definitions in the total samples and also by considering sex, age category, region, education level, and occupation using SPSS crosstab. For univariate analysis, the data were compared between groups by the Student $t$-test or chisquared analysis. Based on our variables (the follow up duration and the CVD event), the Cox proportional hazards model was chosen as the best multivariate approach for analysing survival time data to investigate the association of different definitions of MetS and its components with cardiovascular events. In the first model, the analysis was conducted using a crude model, and in the second model, age, sex, smoking status and physical activity were adjusted to remove the effects of covariates. For all analyses, statistical significance was considered at a level of 0.05. All data were analysed by using Statistical Package for the Social Sciences (IBM SPSS Version 22).

\section{Results}

Overall, 3336 females and 3168 males participated in the first phase of the ICS. When compared between various definitions of MetS, the highest prevalence was observed using the AHA-NHBI definition (36.9\%), followed by JIS (31.2 \%) and ATP III (30.0\%). On the other hand WHO (13.3 \%) and EGIR (8.8 \%) provided a much lower prevalence (Table 2). Considering all definitions, the overall prevalence of MetS was higher in females than in males. Using WHO and EGIR definitions, the prevalence of MetS rose with increasing age, while it increased only until 65-75y using all other definitions.

Table 3 shows the presence of CVD events based on the development of MetS using different definitions. Irrespective of the definitions used, MetS was significantly associated with CVD events. Higher values of CVD risk factors (e.g. age, cholesterol, blood glucose and smoking) were also observed in individuals with CVD events. However, HDL-C was an exception in that there was no significant difference in the levels between the CVD events groups.

The risk of developing CVD, considering all definitions, was approximately two fold higher in the presence
Table 2 Prevalence of metabolic syndrome by sex and age groups based on having MetS using different definitions

\begin{tabular}{|c|c|c|c|c|c|c|}
\hline \multicolumn{7}{|c|}{ MetS definition } \\
\hline & $\mathrm{WHO}$ & EGIR & ATPIII & AHA-NHBI & $\mathrm{IDF}^{\mathrm{a}}$ & JIS \\
\hline Total & $13.3 \%$ & $8.8 \%$ & $30.0 \%$ & $36.9 \%$ & $28.0 \%$ & $31.2 \%$ \\
\hline \multicolumn{7}{|l|}{ Sex } \\
\hline Male & $10.6 \%$ & $6.9 \%$ & $20.7 \%$ & $21.4 \%$ & $25.5 \%$ & $29.1 \%$ \\
\hline Female & $15.9 \%$ & $10.7 \%$ & $38.8 \%$ & $51.7 \%$ & $30.2 \%$ & $33.2 \%$ \\
\hline \multicolumn{7}{|c|}{ Age Categories } \\
\hline $35-45$ & $7.6 \%$ & $5.8 \%$ & $19.9 \%$ & $28.4 \%$ & $19.0 \%$ & $21.2 \%$ \\
\hline $45-55$ & $13.1 \%$ & $8.5 \%$ & $32.7 \%$ & $40.6 \%$ & $31.4 \%$ & $34.2 \%$ \\
\hline $55-65$ & $19.8 \%$ & $12.7 \%$ & $40.1 \%$ & $47.4 \%$ & $37.0 \%$ & $42.2 \%$ \\
\hline $65-75$ & $21.3 \%$ & $13.0 \%$ & $43.4 \%$ & $46.9 \%$ & $37.9 \%$ & $42.3 \%$ \\
\hline$>75$ & $21.9 \%$ & $14.4 \%$ & $30.5 \%$ & $33.3 \%$ & $27.8 \%$ & $33.7 \%$ \\
\hline
\end{tabular}

${ }^{a}$ Waist Circumference $\geq 95$ for both sexes

of MetS (Table 4). As shown in the crude model, the MetS using the WHO definition predicted the highest risk for CVD followed by the JIS definition (HR: 2.41, 95 \% CI: 2.05-2.83 and HR: 2.14, 95 \% CI: 1.86-2.46 respectively). After controlling for possible confounders including age, sex, smoking status and physical activity, the risk of CVD decreased slightly and using the AHANHBI definition was found to be a better predictor than using other definitions (HR: 1.93, $95 \%$ CI: 1.66-2.25). When examining the risk of CVD events for each of the abnormal components of MetS, the risk of CVD occurrence was also significantly higher. Among the components, glucose abnormality was found to be a higher predictor of CVD events (HR: 1.83, 95 \% CI: 1.56-2.15) than the other components.

\section{Discussion}

The present study demonstrated that the prevalence of MetS among Iranian adults varies widely when different definitions are used. Using the WHO and EGIR definitions resulted in a much lower prevalence of MetS when compared with other definitions. Regardless of the definitions, this study also revealed that diagnosing MetS can help identify individuals who are at a higher risk of CVD and can also predict long term CVD events. The AHA-NHBI definition was found to be the best predictor of CVD followed by the WHO and ATPIII definitions; nevertheless, the hazard risk ratios for all definitions were very close.

Researchers have found that multiple endogenous origin risk factors of CVD may accumulate in one person [23]. Thus, MetS has been defined by expert groups as a functional and simple indicator of the risk of CVD, although the predicted risk depends on which definition of MetS is used [23]. Some definitions have emphasised insulin resistance as an essential component for the 
Table 3 Present of cardiovascular events based on different definition of metabolic syndrome

\begin{tabular}{|c|c|c|c|c|}
\hline & & \multicolumn{2}{|c|}{ Cardiovascular event } & \multirow[b]{2}{*}{$P$} \\
\hline & & No & Yes & \\
\hline Presence of MetS by different definitions & MetS (N) & N (\%) & N (\%) & \\
\hline \multirow[t]{2}{*}{ WHO definition } & Yes (766) & $568(11.8)$ & $198(25.5)$ & $<0.001$ \\
\hline & No (4818) & $4241(88.2)$ & $577(74.5)$ & \\
\hline \multirow[t]{2}{*}{ EGIR definition } & Yes (507) & $386(8.0)$ & $121(15.6)$ & $<0.001$ \\
\hline & No (5077) & $4423(92.0)$ & $654(84.4)$ & \\
\hline \multirow[t]{2}{*}{ ATPIII definition } & Yes (1701) & $1337(27.8)$ & $364(47.0)$ & $<0.001$ \\
\hline & No (3883) & $3472(72.2)$ & $411(53.0)$ & \\
\hline \multirow[t]{2}{*}{ AHA-NHBI definition } & Yes (2093) & $1681(35.0)$ & $412(53.2)$ & $<0.001$ \\
\hline & No (3491) & $3128(65.0)$ & $363(46.8)$ & \\
\hline \multirow[t]{2}{*}{ IDF $^{\mathrm{a}}$ definition } & Yes (1595) & $1266(26.3)$ & $329(42.5)$ & $<0.001$ \\
\hline & No (3989) & $3543(73.7)$ & $446(57.5)$ & \\
\hline \multirow[t]{2}{*}{ JIS definition } & Yes (1773) & $1397(29.0)$ & $376(48.5)$ & $<0.001$ \\
\hline & No (3811) & $3412(71.0)$ & $399(51.5)$ & \\
\hline \multicolumn{5}{|l|}{ Cardiovascular risk factors } \\
\hline Age (years) & & $49.8 \pm 11.3$ & $58.0 \pm 11.6$ & $<0.001$ \\
\hline FBS $(\mathrm{mg} / \mathrm{dl})$ & & $87.0 \pm 29.9$ & $101.1 \pm 48.5$ & $<0.001$ \\
\hline Total Cholesterol (mg/dl) & & $212.2 \pm 51.5$ & $228.8 \pm 55.8$ & $<0.001$ \\
\hline $\mathrm{HDL}-\mathrm{C}(\mathrm{mg} / \mathrm{dl})$ & & $46.9 \pm 10.4$ & $47.0 \pm 10.6$ & 0.87 \\
\hline LDL-C (mg/dl) & & $127.6 \pm 42.9$ & $138.4 \pm 46.3$ & $<0.001$ \\
\hline Triglyceride (mg/dl) & & $188.2 \pm 101.7$ & $217.4 \pm 114.5$ & $<0.001$ \\
\hline Waist circumference (cm) & & $94.4 \pm 12.2$ & $97.4 \pm 12.4$ & $<0.001$ \\
\hline BMI & & $26.6 \pm 4.4$ & $27.2 \pm 4.7$ & $<0.001$ \\
\hline Systolic BP (mmHg) & & $120.1 \pm 20.0$ & $133.5 \pm 24.2$ & $<0.001$ \\
\hline Diastolic BP (mmHg) & & $77.7 \pm 11.2$ & $83.1 \pm 12.8$ & $<0.001$ \\
\hline Daily Physical Activity (Mets/h & & $882.4 \pm 544.9$ & $755.1 \pm 562.9$ & $<0.001$ \\
\hline Smoking & & & & $<0.05$ \\
\hline Current smoker & & $769(16.0)$ & $139(18.0)$ & \\
\hline Past smoker & & $270(5.6)$ & $64(8.3)$ & \\
\hline Never smoker & & $3763(78.4)$ & $570(73.7)$ & \\
\hline
\end{tabular}

Data presented as number (percent) or mean \pm Standard deviation

${ }^{a}$ Waist Circumference $\geq 95$ for both sexes

diagnosis of MetS. For instance, according to the WHO definition, without insulin resistance, individuals would not have MetS, even though they have all other criteria [12]. Insulin resistance influences hyperglycemia and diabetes mellitus [24], and increases lipolysis of stored lipids and free fatty acids [25]. Furthermore, it can lead to vasoconstriction and sodium retention which ultimately cause hypertension [26]. Later, abdominal obesity was detected to be strongly associated with insulin resistance [27], impaired glucose tolerance (IGT) [28], hypertension [29], hyperlipidemia [30] and increased risk of coronary heart disease [31]. Abdominal obesity is metabolically active and releases bioactive products such as free fatty acids [32], inflammatory cytokines and adipokines
[33]. Thus, abdominal obesity is implicated as a MetS risk factor, and consequently IDF has considered this kind of obesity to be an essential determinant of the MetS [27].

Surprisingly, it was confirmed that individuals having inherent insulin resistance, such as individuals with South Asian ethnicity, can develop insulin resistance and MetS without an excessive degree of obesity, and even with a WC below the cut off points [34]. In Asian populations the NCEP and ATP III definitions underestimated the population at risk [35]. Due to the ethnic differences, there has been a proposal for using modified cut-off points for defining central obesity as a risk factor for MetS [13]. In the current study, the Iranian National Committee of Obesity cut-off point for WC $(\geq 90 \mathrm{~cm}$ for 
Table 4 Hazard Ratio of CVD occurrence based on different definitions of metabolic syndrome and its components

\begin{tabular}{|c|c|c|c|c|}
\hline Metabolic syndrome definitions & Crude HR (95 \% Cl) & $P$-Value & Adjusted HR ${ }^{\mathrm{b}}(95 \% \mathrm{Cl})$ & $P$-Value \\
\hline $\mathrm{WHO}$ & $2.41(2.05-2.83)$ & $<0.001$ & $1.92(1.62-2.26)$ & $<0.001$ \\
\hline EGIR & $2.03(1.67-2.47)$ & $<0.001$ & $1.66(1.37-2.03)$ & $<0.001$ \\
\hline ATPIII & $2.12(1.84-2.44)$ & $<0.001$ & $1.87(1.61-2.16)$ & $<0.001$ \\
\hline $\mathrm{AHA}-\mathrm{NHBl}$ & $1.98(1.72-2.28)$ & $<0.001$ & $1.93(1.66-2.25)$ & $<0.001$ \\
\hline $\mathrm{IDF}^{\mathrm{a}}$ & $1.93(1.67-2.23)$ & $<0.001$ & $1.65(1.43-1.91)$ & $<0.001$ \\
\hline JIS & $2.14(1.86-2.46)$ & $<0.001$ & $1.80(1.56-2.08)$ & $<0.001$ \\
\hline \multicolumn{5}{|l|}{ Metabolic syndrome components } \\
\hline Obesity & $1.51(1.31-1.75)$ & $<0.001$ & $1.44(1.24-1.67)$ & $<0.001$ \\
\hline High triglyceride & $1.67(1.43-1.95)$ & $<0.001$ & $1.60(1.37-1.87)$ & $<0.001$ \\
\hline High LDL-C & $1.49(1.28-1.74)$ & $<0.001$ & $1.30(1.11-1.52)$ & $<0.01$ \\
\hline Low HDL-C & $1.07(0.91-1.25)$ & 0.404 & $1.19(1.01-1.39)$ & $<0.05$ \\
\hline Hypertension & $2.51(2.18-2.89)$ & $<0.001$ & $1.79(1.53-2.08)$ & $<0.001$ \\
\hline Glucose intolerance/ Diabetes & $2.21(1.88-2.59)$ & $<0.001$ & $1.83(1.56-2.15)$ & $<0.001$ \\
\hline
\end{tabular}

${ }^{a}$ Waist Circumference $\geq 95$ for both sexes

${ }^{\mathrm{b}}$ Adjusted Model for age, sex, smoking status and physical activity

both genders) was used to determine the risk for CVD [36]. Further, it was suggested that there should not be any compulsory components [11].

Previous studies among different population groups in Iran have shown varied prevalence of MetS based on different definitions. However, the patterns of MetS prevalence, using different definitions [9, 37], were very similar to those observed in our study. For instance, in Zabetian et al's study [37], the prevalence of MetS was $32.1,33.2$ and $18.4 \%$ based on the IDF, ATP III, and WHO definitions respectively. In Delavari et al's study [9] its prevalence was 37.4, 34.7 and $41.6 \%$ based on the IDF, ATP III, and AHA/NHLBI criteria respectively. Other studies have also reported that the prevalence of MetS was approximately $30 \%$ in Iranian adults by the ATP III definition [38, 39]. It is likely that using different population criteria, including different age categories, gender ratios, living areas and physical activity levels, might have influenced the reported prevalence of MetS among studies in Iran. Further, the patterns of MetS prevalence in other countries, using different definitions of MetS, have also reported similar variations. An earlier study among Australians reported that one in three was identified with MetS by the IDF definition, while one in five was identified with MstS by using the WHO and ATPIII definitions and it was slightly less when the EGIR definition was used [40].

Previous studies have shown that individuals with MetS were at higher risk of CVD development in the near future (approximately 10 years) even after considering the confounding effects of other major risk factors such as age, sex, smoking, and hypercholesterolemia [41-46] which is in line with our results. Although the current study found that the WHO and IDF criteria for
MetS was related to a high risk for CVD events (HR: 1.92 and 1.65 respectively), their requirements (insulin resistance or abdominal obesity) make it difficult to diagnose high risk individuals without insulin resistance or abdominal obesity. There was also a slight difference in CVD risk between the JIS, AHA-NHBI and ATP III definitions, which was principally because of the variation in their definition and threshold for impaired fasting glucose and WC. The definition which has higher sensitivity and identified a higher number of individuals who are at risk of CVD is the best. In the current study, the AHA-NHBI definition was associated with higher prevalence of MetS, as well as higher CVD risk. Thus, AHA-NHBI definition can be nominated as the best indicator to identify MetS for this study population. On the other hand, as the only difference between the AHA and JIS definitions is the WC threshold, our results showed that the suggested cut-off point for WC in the Iranian population may not be satisfactory and there is a need for redefining the WC cut-off point for the best estimation of CVD risk in this population.

The present study also found a significant association between the risk of CVD and MetS components. The associated risk was higher for glucose intolerance or diabetes (HR: 1.83, 95 \% CI: 1.56-2.15) than any other MetS components, which is in line with previous research [47]. In addition, when the risk of CVD was examined based on the presence of MetS risk factors, more MetS components were associated with a higher risk of cardiovascular events. The risk of CVD for individuals having four and five components of MetS was 2.98 and 6.06 respectively (data not shown). Thus, it may also be necessary to examine the number of components in MetS individuals to identify the individuals 
at higher risk of CVD. Nevertheless, other risk factors of MetS including family history of diseases, age, gender, smoking, LDL or total cholesterol levels should be considered for CVD risk factors [48].

This study has some limitations. First, insulin resistance was not assessed directly, but instead, oral glucose tolerance test was used to estimate insulin sensitivity. Nevertheless, it is accepted that this measurement can be linked with insulin resistance [49]. Further, cohort studies are inherently limited for loss-to-follow up participants. However, the characteristics of individuals did not differ to a great extent as a result of drop-outs. On the other hand, the strength of this study is that to the best of our knowledge, it is the first study that has looked at the HR of CVD events occurrence based on MetS components and different definitions of MetS in a longitudinal study, in urban and rural areas in Eastern Mediterranean countries. Further, this study draws attention to the importance of having a national cut-off point for WC for the Iranian population, which could diagnose the individuals at higher risk of CVD. The present study also emphasises the importance of individual components of MetS for prediction of CVD risk.

\section{Conclusion}

In conclusion, this representative sample of Iranian adults revealed a varied prevalence of MetS when using difference definitions of MetS. Further, follow-up of participants for more than 10 years showed that CVD risk was significantly higher in MetS participants, irrespective of the used definitions, as well as in participants with any risk factors of MetS. Overall, the AHA-NHBI and JIS definitions were better indicators because they were able to capture more individuals with MetS who were not identified by the EGIR and WHO definitions and were also at higher risk of CVD. Finally, the findings of this study emphasise the need for using the best possible population specific indicators for identifying MetS individuals. In addition, there is an urgent need for the development and implementation of appropriate protective measures, including lifestyle modifications, to improve all the MetS components. Control of individual components to prevent cardiovascular events is also necessary.

\footnotetext{
Abbreviations

Mets: Metabolic syndrome; CVD: Cardiovascular disease; ASCVD: Atherosclerotic cardiovascular disease; HDL: High density lipoprotein; ICS: Isfahan cohort study; ICRI: Isfahan Cardiovascular Research Institute; WHO: World Health Organization; FBG: Fasting blood glucose; TC: Total cholesterol; LDL: Low density lipoprotein; VLDL: Very low-density lipoprotein; WC: Waist Circumference; EGIR: European Group for study of Insulin Resistance; NCEP ATP III: National Cholesterol Education Program, Third Adult Treatment Panel; IDF: International Diabetes Foundation; AHA: American Heart Association; NHLBI: National Heart, Lung, and Blood Institute; IFG: Impaired glucose tolerance; JIS: Joint interim statement; AMI: Acute myocardial infarction; UA: Unstable angina; HR: Hazard Ratio; IGT: Impaired glucose tolerance.
}

\section{Competing interests}

The authors declare that they have no competing interests.

\section{Authors' contributions}

HK designed the concept of the study and prepared the draft manuscript. MS, HR and MT effectively worked for the data collection. HK and MD statistically analyzed the data. FA AP and NS provided guidance on the study design and critically reviewed the manuscript. All authors read and approved the final manuscript.

\section{Acknowledgement}

The authors would like to express their gratitude to the Isfahan Cardiovascular Research Institute personnel and especially those involved in the ICS and Isfahan Healthy Heart Program for their sincere assistance.

\section{Author details}

${ }^{1}$ Menzies Health Institute Queensland, and School of Medicine, Griffith University, Gold Coast Campus, QLD, Australia. ${ }^{2}$ Isfahan Cardiac Rehabilitation Research Center, Cardiovascular Research Institue, Isfahan University of Medical Sciences, Isfahan, Iran. ${ }^{3}$ Saw Swee Hock School of Public Health, National University of Singapore, Singapore, Singapore. ${ }^{4}$ Isfahan Cardiovascular Research Center, Cardiovascular Research Institute, Isfahan University of Medical Sciences, Isfahan, Iran.

\section{Received: 14 October 2015 Accepted: 16 December 2015

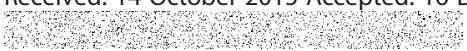

\section{References}

1. Panel NCEPNE. Third Report of the National Cholesterol Education Program (NCEP) expert panel on detection, evaluation, and treatment of high blood cholesterol in adults (adult treatment panel III) final report. Circulation. 2002; 106(25):3143-421.

2. Browning JD, Szczepaniak LS, Dobbins R, Horton JD, Cohen JC, Grundy SM, et al. Prevalence of hepatic steatosis in an urban population in the United States: impact of ethnicity. Hepatology. 2004;40(6):1387-95.

3. Chen L-Y, Qiao Q-H, Zhang S-C, Chen Y-H, Chao G-Q, Fang L-Z. Metabolic syndrome and gallstone disease. World J Gastroenterol. 2012;18(31):4215-20.

4. Lim S, Davies M, Norman R, Moran L. Overweight, obesity and central obesity in women with polycystic ovary syndrome: a systematic review and meta-analysis. Hum Reprod Update. 2012;18(6):618-37.

5. Coughlin SR, Mawdsley L, Mugarza JA, Calverley PM, Wilding JP. Obstructive sleep apnoea is independently associated with an increased prevalence of metabolic syndrome. Eur Heart J. 2004;25(9):735-41.

6. Malik S, Wong ND, Franklin SS, Kamath TV, Gilbert J, Pio JR, et al. Impact of the metabolic syndrome on mortality from coronary heart disease, cardiovascular disease, and all causes in United States adults. Circulation. 2004;110(10):1245-50.

7. van Vliet-Ostaptchouk JV, Nuotio M-L, Slagter SN, Doiron D, Fischer K, Foco L et al. The prevalence of metabolic syndrome and metabolically healthy obesity in Europe: a collaborative analysis of ten large cohort studies. BMC Endocr Disord. 2014;14(1):9.

8. Sarrafzadegan N, Kelishadi R, Esmaillzadeh A, Mohammadifard N, Rabiei K, Roohafza $\mathrm{H}$, et al. Do lifestyle interventions work in developing countries? Findings from the Isfahan Healthy Heart Program in the Islamic Republic of Iran. Bull World Health Organ. 2009:87(1):39-50.

9. Delavari A, Forouzanfar MH, Alikhani S, Sharifian A, Kelishadi R. First nationwide study of the prevalence of the metabolic syndrome and optimal cutoff points of waist circumference in the Middle East the national survey of risk factors for noncommunicable diseases of Iran. Diabetes Care. 2009;32(6):1092-7.

10. Nizal Sarrafzadegan M, Sadeghi M, Shahram Oveisgharan M, Marshall T. Incidence of cardiovascular diseases in an Iranian population: the Isfahan Cohort Study. Arch Iran Med. 2013;16(3):138-44.

11. Alberti K, Eckel R, Grundy S, Zimmet P, Cleeman J, Donato K, et al. International diabetes federation task force on epidemiology and prevention; national heart, lung, and blood institute; American heart association; world heart federation; international atherosclerosis society; international association for the study of obesity. harmonizing the metabolic syndrome: a joint interim statement of the international diabetes federation task force on epidemiology and prevention; national heart, lung, and blood institute; american heart association; world heart federation; international atherosclerosis society; and international association for the study of obesity. Circulation. 2009;120(16):1640-5. 
12. World Health Organization. Definition, diagnosis and classification of diabetes mellitus and its complications. Report of a WHO consultation, vol. 1. Geneva: World Health Organization; 1999.

13. International Diabetes Federation: The IDF consensus worldwide definition of the metabolic syndrome. Brussels, Belgium: IDF Communications; 2006. http://www.idf.org/webdata/docs/IDF_Meta_def_final.pdf.

14. Expert Panel on Detection E, Treatment of High Blood Cholesterol in Adults. Executive summary of the third report of the National Cholesterol Education Program (NCEP) expert panel on detection, evaluation, and treatment of high blood cholesterol in adults (adult treatment panel III). JAMA. 2001;285(19):2486-97.

15. Brown TM, Vaidya D, Rogers WJ, Waters DD, Howard BV, Tardif J-C, et al. Does prevalence of the metabolic syndrome in women with coronary artery disease differ by the ATP III and IDF criteria? J Womens Health. 2008; 17(5):841-7.

16. Sarrafzadegan N, Talaei M, Sadeghi M, Kelishadi R, Oveisgharan S, Mohammadifard N, et al. The Isfahan cohort study: Rationale, methods and main findings. J Hum Hypertens. 2010;25(9):545-53.

17. McNamara JR, Schaefer EJ. Automated enzymatic standardized lipid analyses for plasma and lipoprotein fractions. Clin Chem Acta. 1987;166(1):1-8.

18. Warnick $G$, Nguyen $T$, Albers A. Comparison of improved precipitation methods for quantification of high-density lipoprotein cholesterol. Clin Chem. 1985;31(2):217-22.

19. Friedewald WT, Levy RI, Fredrickson DS. Estimation of the concentration of low-density lipoprotein cholesterol in plasma, without use of the preparative ultracentrifuge. Clin Chem. 1972;18(6):499-502.

20. Balkau B, Charles M-A. Comment on the provisional report from the $\mathrm{WHO}$ consultation. Diabet Med. 1999;16(5):442-3.

21. Alberti K, Zimmet P, Shaw J. Metabolic syndrome-a new world-wide definition. A consensus statement from the international diabetes federation. Diabet Med. 2006;23(5):469-80.

22. Grundy SM, Cleeman JI, Daniels SR, Donato KA, Eckel RH, Franklin BA, et al. Diagnosis and management of the metabolic syndrome an American heart association/national heart, lung, and blood institute scientific statement. Circulation. 2005;112(17):2735-52.

23. He $Y$, Jiang $B$, Wang J, Feng $K$, Chang $Q$, Fan $L$, et al. Prevalence of the metabolic syndrome and its relation to cardiovascular disease in an elderly Chinese population. J Am Coll Cardiol. 2006;47(8):1588-94.

24. Reaven $\mathrm{G}$. The metabolic syndrome or the insulin resistance syndrome? Different names, different concepts, and different goals. Endocrinol Metab Clin North Am. 2004;33(2):283-303.

25. Eckel $R$, Yost $T$, Jensen $D$. Alterations in lipoprotein lipase in insulin resistance. Int J Obes Relat Metab Disord. 1995;19:S16-21.

26. Ferrannini E, Buzzigoli G, Bonadonna R, Giorico MA, Oleggini M, Graziadei L, et al. Insulin resistance in essential hypertension. N Engl J Med. 1987;317(6):350-7.

27. Carr DB, Utzschneider KM, Hull RL, Kodama K, Retzlaff BM, Brunzell JD, et al. Intra-abdominal fat is a major determinant of the national cholesterol education program adult treatment panel III criteria for the metabolic syndrome. Diabetes. 2004;53(8):2087-94

28. Hayashi T, Boyko EJ, Leonetti DL, McNeely MJ, Newell-Morris L, Kahn SE, et al. Visceral adiposity and the risk of impaired glucose tolerance a prospective study among Japanese Americans. Diabetes Care. 2003;26(3):650-5.

29. Rattarasarn C, Leelawattana R, Soonthornpun S, Setasuban W, Thamprasit A, Lim A, et al. Regional abdominal fat distribution in lean and obese Thai type 2 diabetic women: relationships with insulin sensitivity and cardiovascular risk factors. Metabolism. 2003;52(11):1444-7.

30. Nicklas BJ, Penninx BW, Ryan AS, Berman DM, Lynch NA, Dennis KE. Visceral adipose tissue cutoffs associated with metabolic risk factors for coronary heart disease in women. Diabetes Care. 2003:26(5):1413-20.

31. Lamarche B, Lemieux S, Dagenais G, Després J-P. Visceral obesity and the risk of ischaemic heart disease: insights from the Quebec Cardiovascular Study. Growth Horm IGF Res. 1998;8:1-8.

32. van Harmelen $V$, Dicker $A$, Rydén $M$, Hauner $H$, Lönnqvist $F$, Näslund $E$, et al Increased lipolysis and decreased leptin production by human omental as compared with subcutaneous preadipocytes. Diabetes. 2002;51(7):2029-36

33. Yatagai T, Nagasaka S, Taniguchi A, Fukushima M, Nakamura T, Kuroe A, et al. Hypoadiponectinemia is associated with visceral fat accumulation and insulin resistance in Japanese men with type 2 diabetes mellitus. Metabolism. 2003;52(10):1274-8.
34. Abate N, Chandalia M, Snell PG, Grundy SM. Adipose tissue metabolites and insulin resistance in nondiabetic Asian Indian men. J Clin Endocrinol Metab. 2004;89(6):2750-5.

35. Tan C-E, Ma S, Wai D, Chew S-K, Tai E-S. Can we apply the National Cholesterol Education Program Adult Treatment Panel definition of the metabolic syndrome to Asians? Diabetes Care. 2004;27(5):1182-6.

36. Fereidoun Azizi M, Davood Khalili M, Hassan Aghajani M, Alireza Esteghamati M, Farhad Hosseinpanah M, Alireza Delavari M, et al. Appropriate waist circumference cut-off points among Iranian adults: the first report of the Iranian National Committee of Obesity. Arch Iran Med. 2010;13(3):243.

37. Zabetian A, Hadaegh F, Azizi F. Prevalence of metabolic syndrome in Iranian adult population, concordance between the IDF with the ATPIII and the WHO definitions. Diabetes Res Clin Pract. 2007;77(2):251-7.

38. Azizi F, Salehi P, Etemadi A, Zahedi-Asl S. Prevalence of metabolic syndrome in an urban population: Tehran Lipid and Glucose Study. Diabetes Res Clin Pract. 2003;61(1):29-37.

39. Sarrafzadegan N, Kelishadi R, Baghaei A, Sadri GH, Malekafzali H, Mohammadifard N, et al. Metabolic syndrome: an emerging public health problem in Iranian women: Isfahan Healthy Heart Program. Int J Cardiol. 2008;131(1):90-6.

40. Cameron AJ, Magliano DJ, Zimmet PZ, Welborn T, Shaw JE. The metabolic syndrome in Australia: prevalence using four definitions. Diabetes Res Clin Pract. 2007;77(3):471-8.

41. Isomaa B, Almgren P, Tuomi T, Forsén B, Lahti K, Nissén M, et al. Cardiovascular morbidity and mortality associated with the metabolic syndrome. Diabetes Care. 2001;24(4):683-9.

42. Girman CJ, Rhodes T, Mercuri M, Pyörälä K, Kjekshus J, Pedersen TR, et al. The metabolic syndrome and risk of major coronary events in the Scandinavian Simvastatin Survival Study (4S) and the Air Force/Texas coronary atherosclerosis prevention study (AFCAPS/TexCAPS). Am J Cardiol. 2004;93(2):136-41.

43. Olijhoek JK, van der Graaf Y, Banga J-D, Algra A, Rabelink TJ, Visseren FL. The metabolic syndrome is associated with advanced vascular damage in patients with coronary heart disease, stroke, peripheral arterial disease or abdominal aortic aneurysm. Eur Heart J. 2004;25(4):342-8.

44. Mottillo S, Filion KB, Genest J, Joseph L, Pilote L, Poirier P, et al. The metabolic syndrome and cardiovascular risk: a systematic review and meta-analysis. J Am Coll Cardiol. 2010;56(14):1113-32.

45. Gami AS, Witt BJ, Howard DE, Erwin PJ, Gami LA, Somers VK, et al. Metabolic syndrome and risk of incident cardiovascular events and death: a systematic review and meta-analysis of longitudinal studies. J Am Coll Cardiol. 2007; 49(4):403-14.

46. Galassi A, Reynolds K, He J. Metabolic syndrome and risk of cardiovascular disease: a meta-analysis. Am J Med. 2006;119(10):812-9.

47. Bonora E, Kiechl S, Willeit J, Oberhollenzer F, Egger G, Meigs JB, et al. Population-based incidence rates and risk factors for type 2 diabetes in White individuals The Bruneck Study. Diabetes. 2004;53(7):1782-9.

48. Huang PL. A comprehensive definition for metabolic syndrome. Dis Mode Mech. 2009;2(5-6):231-7.

49. Stumvoll M, Mitrakou A, Pimenta W, Jenssen T, Yki-Järvinen $H$, Van Haeften T, et al. Use of the oral glucose tolerance test to assess insulin release and insulin sensitivity. Diabetes Care. 2000;23(3):295-301.

\section{Submit your next manuscript to BioMed Central and we will help you at every step:}

- We accept pre-submission inquiries

- Our selector tool helps you to find the most relevant journal

- We provide round the clock customer support

- Convenient online submission

- Thorough peer review

- Inclusion in PubMed and all major indexing services

- Maximum visibility for your research

Submit your manuscript at www.biomedcentral.com/submit 